\title{
The Role of SNPs in ILIRLI and ILIRAP Genes in Age-related Macular Degeneration Development and Treatment Efficacy
}

\author{
ALVITA VILKEVICIUTE ${ }^{1}$, NERINGA BASTIKAITYTE ${ }^{2}$, RUTA MOCKUTE ${ }^{3}$, DZASTINA CEBATORIENE ${ }^{3}$, \\ LORESA KRIAUCIUNIENE $^{1,3}$, JURATE BALCIUNIENE $^{3}$, REDA ZEMAITIENE $^{3}$ and RASA LIUTKEVICIENE RE $^{1,3}$ \\ ${ }^{1}$ Neuroscience Institute, Lithuanian University of Health Sciences, Medical Academy, Kaunas, Lithuania; \\ ${ }^{2}$ Lithuanian University of Health Sciences, Medical Academy, Kaunas, Lithuania; \\ ${ }^{3}$ Department of Ophthalmology, Lithuanian University of Health Sciences, Medical Academy, Kaunas, Lithuania;
}

\begin{abstract}
Background: Age-related macular degeneration (AMD) affects the central part of the retina and causes blindness. In developed countries, AMD occurs in people over 50 years old. Important factors for AMD pathogenesis are an immune response, inflammation, and genetic factors. This study aimed to determine the impact of ILIRLI rs1041973 and ILIRAP rs4624606 single nucleotide polymorphisms (SNPS) on the occurrence of AMD and the outcome of treatment with aflibercept and bevacizumab. Patients and Methods: 563 patients with AMD and 281 healthy candidates were evaluated. Patients with exudative $A M D$ were treated with intravitreal bevacizumab and aflibercept and, after 6 months based on the changes in bestcorrected visual acuity and central macular thickness, were classified as 'responders' or 'poor-responders'. Genotyping of ILIRLI rs1041973 and ILIRAP rs4624606 was accomplished using real-time PCR. Age was compared using the Mann-Whitney U-test. Categorical data (gender, genotype, and allele distributions) compared between groups using the $\chi^{2}$ test or the Fisher's exact test. Associations of gene polymorphisms were calculated using logistic regression analysis with adjustment for age in exudative and atrophic AMD analysis. An adjusted significance threshold for multiple comparisons $\alpha=0.025$ was applied. Results: Statistically significant differences in the distribution of ILIRAP rs4624606 genotypes (TT, TA and AA) were found between males with atrophic AMD and controls: $50 \%, 42.9 \%$
\end{abstract}

This article is freely accessible online.

Correspondence to: Alvita Vilkeviciute, Neuroscience Institute, Laboratory of Ophthalmology, Lithuanian University of Health Sciences, Medical Academy, Eiveniu 2, Kaunas 50161, Lithuania. Tel: +37037326018,e-mail: alvita.vilkeviciute@1smuni.lt

Key Words: Age-related macular degeneration, IL1RL1 rs1041973, IL1RAP rs4624606, gene polymorphisms, treatment. and $7.1 \%$ vs. $69.7 \%, 30.3 \%$ and $0 \%$, respectively, $p=0.015$. Moreover, we found that 'responders' had a significantly better best-corrected visual acuity than 'poor-responders' before treatment $(p=0.032)$. The central macular thickness was significantly lower in exudative AMD patients with IL1RL1 rs1041973 AA genotype than in wild type and heterozygous $(C C+C A)$ genotype carriers before treatment ( $p=0.017$ ). Conclusion: IL1RAP rs4624606 may be associated with atrophic AMD in males while ILIRLI rs1041973 may play a protective role against macular thickening in exudative AMD patients.

Age-related macular degeneration (AMD), the leading cause of blindness in developed countries, is a complex disease caused entirely by environmental, demographic, and genetic factors $(1,2)$. AMD is classified into early or intermediate stages with the formation of drusen, an amorphous extracellular deposit in the retina, and characteristic pigmentary changes, and late stages, which may either be atrophic (geographic atrophy) or wet (neovascular type) (3). Early stages of the disease are often clinically asymptomatic. It progresses slowly and evolves into late AMD only in 10$20 \%$ of patients, of which two-thirds have neovascular and one-third atrophic AMD type (4). Late forms are characterized by the irreversible loss of central vision. Treatment in clinical practice is currently available only for the neovascular type: intraocular injections with VEGF inhibitors; there are no clinically approved treatment options for atrophic AMD and/or the possibility to stop early AMD forms developing to advanced AMD forms. Currently, an estimated 10.1 million people are living with AMD projected global cases are 11.3, 14.9, and 18.6 million for 2020, 2030, and 2040, respectively (5).

In recent years, there has been growing evidence pointing to inflammatory processes and genetic components as having strong effects on AMD development (6-8). Knowledge of the molecular genetics of AMD has emerged mainly from analyses of DNA sequence and structural variations, with the 
Table I. Demographic data of the studied groups.

\begin{tabular}{|c|c|c|c|c|c|}
\hline & $\begin{array}{l}\text { Early AMD group } \\
n=270\end{array}$ & $\begin{array}{l}\text { Exudative AMD group } \\
n=293\end{array}$ & $\begin{array}{l}\text { Atrophic AMD group } \\
n=53\end{array}$ & $\begin{array}{c}\text { Control group } \\
\mathrm{n}=281\end{array}$ & $p$-Value \\
\hline Males, n (\%) & $82(30.4)$ & $105(35.8)$ & $14(26.4)$ & $99(35.2)$ & $\begin{array}{l}0.225^{*} \\
0.880 * * \\
0.213 * * *\end{array}$ \\
\hline Females, n (\%) & $188(69.6)$ & $188(64.2)$ & $39(73.6)$ & $182(64.8)$ & \\
\hline Age median $/ \mathrm{min} / \max$ & $74 / 59 / 94$ & $77 / 61 / 95$ & $80 / 61 / 97$ & $73 / 59 / 94$ & $\begin{array}{c}0.065^{*} \\
<\mathbf{0 . 0 0 1}^{* *} \\
<\mathbf{0 . 0 0 1}^{* *}\end{array}$ \\
\hline Responders, n (\%) & - & $75(83.3)$ & & & \\
\hline Poor-responders, n (\%) & & $15(16.7)$ & - & - & - \\
\hline
\end{tabular}

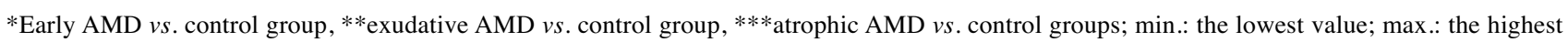
value. Bold values show statistical significance.

large-scale genome-wide association studies (GWAS) reporting findings on the polygenic nature and incomplete penetrance of many common DNA variants associated with the disease $(9,10)$. Interleukin-1 receptor type I (IL1R1), also known as cluster of differentiation 121a (CD121a), is an interleukin receptor. IL1R1 also denotes its human gene. IL1RL1 has gained recognition due to its involvement in immune/inflammatory disorders (11). Interleukin-1 receptor accessory protein in humans is encoded by the ILIRAP gene. It has been shown that interleukin 1 induces synthesis of the acute phase and proinflammatory proteins during infection, tissue damage, or stress by forming a complex at the cell membrane with an interleukin 1 receptor and an accessory protein. The protein is a necessary part of the interleukin-1 receptor complex, which initiates signaling events that result in the activation of interleukin-1 responsive genes. Alternative splicing of this gene results in two transcript variants encoding two different isoforms, one membrane-bound and one soluble. The ratio of soluble to membrane-bound forms increases during acute-phase induction or stress (12). Madore et al. have found that the strongest gene-gene statistical interaction is between the ILIRAP and ILIRI genes and it has the most biological relevance. These genes encode proteins that are associated with the regulation of the IL- 1 receptor and the functionality of IL-1 (13). Indeed, IL-1R1 and IL1RAP have been shown to form a protein complex with IL1 , and the interplay between these proteins may serve to unbalance the interaction between IL-1 and its signaling receptor (IL-1R1 and IL-1RAP) and its decoy receptor complex (IL-1R2 and IL-1RAP). Furthermore, it has been shown that inhibition of IL1R1 in mice with increased VEGF-A expression reduces severe degenerative and atrophic changes of the retinal pigment epithelium (RPE), thick basal laminar sub-RPE deposits, shortening of photoreceptor outer and inner segments, and attenuation of the photoreceptor outer nuclear layer (14). Also, we hypothesized that each individual's genetic variations can determine the exudative AMD treatment response to intravitreal injections and that identified genetic markers, predicting the differentiated response, may improve personalized medicine.

Our research aimed to elucidate the possible involvement of ILIRLI rs1041973 and ILIRAP rs4624606 gene polymorphisms in early and exudative AMD development in the Lithuanian population and analyze the outcome of exudative AMD treatment.

\section{Patients and Methods}

Patients and study design. The study was approved by the Ethics Committee for Biomedical Research, Lithuanian University of Health Sciences (No. BE-2-/13). A total of 897 individuals participated in this study: 270 patients with early AMD, 293 patients with exudative AMD, 53 patients with atrophic AMD, and the healthy control group consisted of 281 individuals (Table I). Participants were involved in our study according to previously published criteria (15). Study subjects underwent ophthalmological evaluation and general examination (15). DNA extraction and genotyping were performed as described in our previous publication (15). The distribution of males and females among the early, exudative and atrophic AMD and control groups did not differ statistically significantly $(p=0.225, \quad p=0.880$ and $p=0.213$, respectively) (Table I). The age of controls matched the age of early AMD patients $(p=0.065)$, but controls were younger than patients with exudative and atrophic AMD ( $p<0.001$ for both) (Table I).

Exudative AMD treatment efficacy evaluation. Exudative AMD patients were treated with intraocular injections with VEGF inhibitors. Every 8 weeks, $2 \mathrm{mg}$ of aflibercept and every 4 weeks $1.25 \mathrm{mg}$ of bevacizumab (after three initial monthly injections) were given until choroidal neovascularization (CNV) was no longer active. Signs of active neovascularization were defined as fluid on OCT, new or persistent hemorrhage, decreased visual acuity as compared with the previous examination, or dye leakage or increased lesion size on fluorescein angiography. Best-corrected visual acuity (BCVA) and the central macular thickness were evaluated in 90 patients treated for exudative AMD. We chose to evaluate BCVA and 
Table II. The impact of IL1RL1 rs1041973 and IL1RAP rs4624606 on early age-related macular degeneration (AMD) development.

Early AMD

ILIRL1 rs1041973

\begin{tabular}{|c|c|c|c|c|}
\hline Model & Genotype/allele & OR $(95 \% \mathrm{CI})$ & $p$-Value & AIC \\
\hline \multirow[t]{2}{*}{ Codominant } & $\mathrm{CA} v s . \mathrm{CC}$ & $1.423(1.001-2.002)$ & 0.050 & 763.479 \\
\hline & AA vs. CC & $0.978(0.503-1.900)$ & 0.948 & \\
\hline Dominant & $\mathrm{CA}+\mathrm{AA} v s . \mathrm{CC}$ & $1.342(0.960-1.878)$ & 0.085 & 762.661 \\
\hline Recessive & $\mathrm{AA} v s . \mathrm{CA}+\mathrm{CC}$ & $0.841(0.440-1.605)$ & 0.599 & 428.377 \\
\hline Overdominant & $\mathrm{CA}$ vs. $\mathrm{CC}+\mathrm{AA}$ & $1.426(1.013-2.009)$ & 0.042 & 761.483 \\
\hline Additive & $\mathrm{A}$ & $1.170(0.896-1.528)$ & 0.249 & 764.299 \\
\hline
\end{tabular}

IL1RAP rs4624606

\begin{tabular}{|c|c|c|c|c|}
\hline \multirow[t]{2}{*}{ Codominant } & TA vs. TT & $1.163(0.801-1.687)$ & 0.428 & 765.443 \\
\hline & AA $v s . \mathrm{TT}$ & $2.209(0.654-7.458)$ & 0.202 & \\
\hline Dominant & $\mathrm{TA}+\mathrm{AA} v s . \mathrm{TT}$ & $1.215(0.845-1.747)$ & 0.294 & 764.524 \\
\hline Recessive & $\mathrm{AA} v s . \mathrm{TA}+\mathrm{TT}$ & $2.115(0.629-7.106)$ & 0.226 & 764.072 \\
\hline Overdominant & $\mathrm{TA} v s . \mathrm{TT}+\mathrm{AA}$ & $1.136(0.784-1.646)$ & 0.501 & 765.176 \\
\hline Additive & $\mathrm{A}$ & $1.240(0.895-1.719)$ & 0.196 & 763.952 \\
\hline
\end{tabular}

OR: Odds ratio; CI: confidence interval; AIC: Akaike information criterion. Bold values show statistical significance.

central macular thickness changes before treatment and at 3 and 6 months after treatment. According to these data, we divided patients with exudative AMD into two subgroups: responders and poorresponders (Table I). 'Poor-responders' had at least two of the three signs: persistence of submacular fluid, decreased visual acuity or increased central macular thickness $(\geq 100$ micrometers $)$. 'Responders' did not have any of the mentioned signs.

Statistical analysis. Statistical analysis was performed using the SPSS/W 20.0 software (Statistical Package for the Social Sciences for Windows, Inc., Chicago, Illinois, USA). Age is presented as median, minimum (min.) and maximum (max.) values and compared using the Mann-Whitney $U$-test. Categorical data (gender, genotype, and allele distributions) are presented as absolute numbers with percentages in brackets and compared between the early, exudative, and atrophic AMD and control groups using the $\chi^{2}$ test or the Fisher exact test.

Associations of gene polymorphisms were calculated using logistic regression analysis and present odds ratios (OR) with $95 \%$ confidence intervals (CI). Adjustment for age was done in exudative and atrophic AMD analysis. Due to multiple association calculations, we introduced an adjusted significance threshold for multiple comparisons $\alpha=0.025(0.05 / 2$, since we analyzed 2 different SNPs). The impact of genotypes is expressed as genetic models (codominant: heterozygotes versus wild type homozygotes and minor allele homozygotes versus wild type homozygotes; dominant: minor allele homozygotes and heterozygotes versus wild type homozygotes; recessive: minor allele homozygotes versus wild type homozygotes and heterozygotes; overdominant: heterozygotes versus wild type homozygotes and minor allele homozygotes; the additive model was used to evaluate the impact of each minor allele on AMD development). The selection of the best genetic model was based on the Akaike Information Criterion (AIC); therefore, the best genetic models were those with the lowest AIC values.

\section{Results}

Hardy-Weinberg equilibrium. We estimated the distributions of rs1041973 and rs4624606 genotypes in the control group using Hardy-Weinberg equilibrium (HWE). Both SNPs were in HWE $(p>0.05)$ (Supplementary material).

ILIRL1 rs1041973 and ILIRAP rs4624606 analysis in AMD. We analyzed ILIRL1 rs1041973 and ILIRAP rs4624606 polymorphisms in the early, exudative, and atrophic AMD, and control groups. The analysis results did not reveal any differences between ILIRL1 rs1041973 and ILIRAP rs4624606 genotype and allele distributions in the early, exudative, and atrophic AMD groups (Supplementary material).

The binary logistic regression analysis showed that ILIRL1 rs1041973 CA genotype was associated with 1.4fold increased odds of early AMD development $(\mathrm{OR}=1.426$. $\mathrm{CI}=1.013-2.009, p=0.042$ ) (Table II) and 1.9-fold increased odds of atrophic AMD development $(\mathrm{OR}=1.883$. $\mathrm{CI}=1.011$ 3.507, $p=0.046$ ) (Table III); unfortunately, the results were not statistically significant according to the Bonferroni correction $(p>0.025)$. No statistically significant associations were found in the exudative AMD group (Supplementary material).

ILIRL1 rs1041973 and ILIRAP rs4624606 analysis in AMD by gender. SNPs analysis performed by gender did not reveal any statistically significant associations in the early and exudative AMD groups (Supplementary material). Statistically significant differences in the distribution of ILIRAP rs4624606 
in vivo $34: 2443-2451(2020)$

Table III. The impact of IL1RL1 rs1041973 and IL1RAP rs4624606 on atrophic age-related macular degeneration (AMD) development.

Atrophic AMD

\begin{tabular}{|c|c|c|c|c|}
\hline \multicolumn{5}{|c|}{ IL1RL1 rs1041973 } \\
\hline Model & Genotype/allele & $\mathrm{OR} *(95 \% \mathrm{CI})$ & $p$-Value & AIC \\
\hline \multirow[t]{2}{*}{ Codominant } & CA vs. CC & $1.829(0.968-3.455)$ & 0.063 & \multirow[t]{2}{*}{262.581} \\
\hline & AA vs. CC & $0.734(0.154-3.502)$ & 0.698 & \\
\hline Dominant & $\mathrm{CA}+\mathrm{AA} v s . \mathrm{CC}$ & $1.658(0.890-3.087)$ & 0.111 & 262.154 \\
\hline Recessive & $\mathrm{AA} v s . \mathrm{CA}+\mathrm{CC}$ & $0.553(0.120-2.554)$ & 0.448 & 264.060 \\
\hline Overdominant & $\mathrm{CA} v s . \mathrm{CC}+\mathrm{AA}$ & $1.883(1.011-3.507)$ & 0.046 & 260.741 \\
\hline Additive & $\mathrm{A}$ & $1.285(0.787-2.099)$ & 0.317 & 263.728 \\
\hline \multicolumn{5}{|c|}{ IL1RAP rs4624606 } \\
\hline \multirow[t]{2}{*}{ Codominant } & TA $v s . \mathrm{TT}$ & $1.371(0.706-2.664)$ & 0.352 & \multirow[t]{2}{*}{264.674} \\
\hline & AA vs. TT & $3.350(0.490-22.881)$ & 0.218 & \\
\hline Dominant & $\mathrm{TA}+\mathrm{AA} v s . \mathrm{TT}$ & $1.457(0.765-2.777)$ & 0.253 & 263.429 \\
\hline Recessive & $\mathrm{AA} v s . \mathrm{TA}+\mathrm{TT}$ & $3.031(0.449-20.478)$ & 0.255 & 263.527 \\
\hline Overdominant & $\mathrm{TA} v s . \mathrm{TT}+\mathrm{AA}$ & $1.316(0.681-2.543)$ & 0.414 & 264.058 \\
\hline Additive & $\mathrm{A}$ & $1.491(0.836-2.659)$ & 0.176 & 262.934 \\
\hline
\end{tabular}

*Adjusted for age; OR: odds ratio; CI: confidence interval; AIC: Akaike information criterion. Bold values show statistical significance.

Table IV. Distributions of IL1RL1 rs1041973 and IL1RAP rs4624606 genotypes and alleles in control and atrophic age-related macular degeneration $(A M D)$ groups by gender.

\begin{tabular}{|c|c|c|c|c|c|c|c|}
\hline \multirow[t]{2}{*}{ SNP } & \multirow{2}{*}{$\begin{array}{l}\text { Genotypes/ } \\
\text { alleles }\end{array}$} & \multicolumn{2}{|c|}{ Males } & \multirow[t]{2}{*}{$p$-Value } & \multicolumn{2}{|c|}{ Females } & \multirow[t]{2}{*}{$p$-Value } \\
\hline & & $\begin{array}{c}\text { Control } \\
\mathrm{n}(\%) \\
(\mathrm{n}=99)\end{array}$ & $\begin{array}{c}\text { Atrophic AMD } \\
\mathrm{n}(\%) \\
(\mathrm{n}=14)\end{array}$ & & $\begin{array}{l}\text { Control } \\
\mathrm{n}(\%) \\
(\mathrm{n}=182)\end{array}$ & $\begin{array}{c}\text { Atrophic AMD } \\
\mathrm{n}(\%) \\
(\mathrm{n}=39)\end{array}$ & \\
\hline \multirow[t]{5}{*}{ IL1RL1 rs 1041973} & $\mathrm{CC}$ & $57(57.6)$ & $7(50.0)$ & \multirow[t]{3}{*}{0.575} & $102(56.0)$ & $16(41.0)$ & \multirow[t]{3}{*}{0.064} \\
\hline & $\mathrm{CA}$ & $38(38.4)$ & $7(50.0)$ & & $62(34.1)$ & $21(53.8)$ & \\
\hline & AA & $4(4.0)$ & $0(0)$ & & $18(9.9)$ & $2(5.1)$ & \\
\hline & $\mathrm{C}$ & $152(76.8)$ & $21(75.0)$ & \multirow[t]{2}{*}{0.814} & $266(73.1)$ & $53(67.9)$ & \multirow[t]{2}{*}{0.404} \\
\hline & A & $46(23.2)$ & $7(25.0)$ & & $98(26.9)$ & $25(32.1)$ & \\
\hline \multirow[t]{5}{*}{ ILIRAP rs4624606 } & TT & $69(69.7)$ & $7(50.0)$ & \multirow[t]{3}{*}{0.015} & $132(72.5)$ & $26(66.7)$ & \multirow[t]{3}{*}{0.762} \\
\hline & TA & $30(30.3)$ & $6(42.9)$ & & $46(25.3)$ & $12(30.8)$ & \\
\hline & AA & $0(0)$ & $1(7.1)$ & & $4(2.2)$ & $1(2.6)$ & \\
\hline & $\mathrm{T}$ & $168(84.8)$ & $20(71.4)$ & \multirow[t]{2}{*}{0.102} & $310(85.2)$ & $64(82.1)$ & \multirow[t]{2}{*}{0.491} \\
\hline & A & $30(15.2)$ & $8(28.6)$ & & $54(14.8)$ & $14(17.9)$ & \\
\hline
\end{tabular}

Bold values show statistical significance.

genotypes (TT, TA an AA) were found between males with atrophic AMD and controls: $50 \%, 42.9 \%$ and $7.1 \%$ vs. $69.7 \%$, $30.3 \%$ and $0 \%$, respectively $(p=0.015)$ (Table IV).

Exudative AMD treatment efficacy. We evaluated the treatment response of exudative AMD and differentiated patients into 'responders' and 'poor-responders'. Best-corrected visual acuity (BCVA) and the macular thickness before treatment and after 3 and 6 months, as well as macular thickness changes after 6 months, were compared between 'responders' and 'poor-responders' (Table V). We found that before treatment, 'responders' had significantly better BCVA than 'poorresponders' ( $p=0.032$ ) (Table V). None of the other parameters reached significant differences between the groups. 
Table V. Best-corrected visual acuity and macular thickness in 'responders' and 'poor-responders'.

\begin{tabular}{|c|c|c|c|c|}
\hline Parameter & Measurement time & $\begin{array}{c}\text { Responders } \\
\text { Median (IQR) }\end{array}$ & $\begin{array}{l}\text { Poor-responders } \\
\text { Median (IQR) }\end{array}$ & $p$-Value \\
\hline \multirow[t]{3}{*}{ Central macular thickness (micrometres) } & Before treatment & 337 (97.5) & $288(106.5)$ & 0.061 \\
\hline & After 3 months & $279(102.75)$ & $286.5(101.5)$ & 0.730 \\
\hline & After 6 months & $276(87.75)$ & $327(111.5)$ & 0.094 \\
\hline \multirow[t]{3}{*}{ BCVA } & Before treatment & $0.30(0.24)$ & $0.046(0.45)$ & 0.032 \\
\hline & After 3 months & $0.40(0.30)$ & $0.30(0.50)$ & 0.594 \\
\hline & After 6 months & $0.35(0.25)$ & $0.30(0.35)$ & 0.155 \\
\hline Central macular thickness changes & After 6 months & $28.5(99.5)$ & $75.5(-)$ & 0.387 \\
\hline
\end{tabular}

BCVA: Best-corrected visual acuity. Bold values show statistical significance.

Table VI. Associations between IL1RL1 rs1041973 and central macular thickness and best-corrected visual acuity.

\begin{tabular}{|c|c|c|c|c|}
\hline Parameter & Measurement time & $\begin{array}{c}\mathrm{CC}+\mathrm{CA} \\
\text { Median (IQR) }\end{array}$ & $\begin{array}{c}\text { AA } \\
\text { Median (IQR) }\end{array}$ & $p$-Value \\
\hline \multirow[t]{3}{*}{ Central macular thickness (micrometres) } & Before treatment & $338(95)$ & $251(82)$ & 0.017 \\
\hline & After 3 months & $280(115)$ & $270(30)$ & 0.740 \\
\hline & After 6 months & $283(108)$ & $266(146)$ & 0.594 \\
\hline Central macular thickness changes & After 6 months & $33(98)$ & $-7(68)$ & 0.104 \\
\hline \multirow[t]{3}{*}{ BCVA } & Before treatment & $0.30(0.21)$ & $0.45(0.41)$ & 0.157 \\
\hline & After 3 months & $0.40(0.3)$ & $0.50(0.51)$ & 0.266 \\
\hline & After 6 months & $0.34(0.28)$ & $0.45(0.39)$ & 0.297 \\
\hline \multirow[t]{2}{*}{ BCVA changes } & After 3 months & $0.00(0.11)$ & $0.05(0.13)$ & 0.621 \\
\hline & After 6 months & $0.04(0.11)$ & $0.00(0.04)$ & 0.447 \\
\hline
\end{tabular}

BCVA: Best-corrected visual acuity. Bold values show statistical significance.

In further analysis, we compared the distributions of ILIRLI rs1041973 and ILIRAP rs4624606 genotypes and alleles between these two groups; however, there were no differences found (Supplementary material). On the other hand, we revealed the association between ILIRLI rs 1041973 homozygous minor allele carriers (AA) and the central macular thickness before treatment. The macular thickness was significantly lower in exudative AMD patients with AA genotype than in wild type and heterozygous (CC+CA) genotype carriers [median (IQR): 338 (95) vs. 251 (82), $p=0.017$ ] (Table VI). No associations were found between ILIRLI rs 1041973 and BCVA (Table VI). ILIRAP rs4624606 analysis showed no associations with the macular thickness or BCVA, which may be caused by a very small number of ILIRAP rs4624606 homozygous minor allele carriers (Supplementary material).

\section{Discussion}

To our knowledge, this is the first time that ILIRLI rs 1041973 and ILIRAP rs4624606 gene polymorphisms associations with early, exudative, and atrophic AMD development and exudative AMD treatment efficacy are analyzed.
Our results revealed that the IL1RL1 rs1041973 CA genotype was associated with 1.4-fold increased odds of early AMD development $(p=0.042)$ and 1.9-fold increased odds of atrophic AMD development ( $p=0.046)$; however, the Bonferroni correction did not allow us to confirm this association as statistically significant. Also, we found that central macular thickness was significantly lower in exudative AMD patients with AA genotype than in wild type and heterozygous $(\mathrm{CC}+\mathrm{CA})$ genotype carriers before treatment [median (IQR): 338 (95) vs. 251 (82), $p=0.017$ ].

ILIRL1 is located in an interleukin 1 (IL1) receptor gene cluster on chromosome 2q12 (17). Human ILIRLI encodes the receptor for interleukin-33 (IL33) and has three isoforms, including soluble IL1RL1 (IL1RL1-a), that can modify T helper cell responses by inhibition of IL33 signaling (18). IL1RL1-a can be induced by pro-inflammatory stimuli and appears to be essential for the normal function of $\mathrm{T}$ helper cells $(17,19)$. Serum levels of IL1RL1 were found elevated in atopic asthmatic patients during acute exacerbations (20). Marneros has analyzed the VEGF-a induced aging diseases of the eye and found that targeting NLRP3 inflammasome components or Il1r1 strongly inhibited both neovascular and non-exudative AMD-like pathologies (14). Other scientist groups have also proved that ILIRLI genetic polymorphisms 
and IL1RL1-a serum levels are associated with severe arthritis, acute heart disease, and airway disease such as asthma (21-25). Also, studies are analyzing the association of other diseases, mostly asthma, with ILIRLI gene polymorphisms. SNPs in ILIRLI are associated with asthmarelated phenotypes in three studies (26-28). Given the role of eosinophils in the pathogenesis of asthma, alleles that are associated with increased eosinophil count could be detrimental in terms of asthma risk and severity. In a GWAS of eosinophil count in an Icelandic population, an SNP in ILIRL1 (rs1420101) showed the most significant association. The A allele of rs1420101 is associated with an increased eosinophil count and, in further analyses, with increased serum IgE as well as with three asthma phenotypes (asthma, atopic asthma, nonatopic asthma) in nine European populations and one East Asian population (28).

Two (rs1041973 and rs10206753) of the four coding nonsynonymous ILIRLI SNPs, associated with asthma in the Mexican population, were also examined in a Dutch population where they showed no associations (26).

Another gene we evaluated in patients with AMD was ILIRAP rs4624606. IL1RAP is commonly known to be the co-receptor for the IL-1 receptor and it is required to transduce IL-1 signaling, leading to pro-inflammatory gene expression and cell survival (29). The $I L-1 R A c P$ gene is located on chromosome 3q28 (30).

Furthermore, Theodoropoulou et al. have demonstrated that IL-1 receptor accessory protein (IL1RAP) is expressed by cells in the murine retina and retinal pigment epithelium (RPE). They have sought to determine whether similar expression profiles were present in healthy human ocular tissue and revealed robust expression of IL1RAP in the nerve fiber layer of the inner retina and the RPE (31). In our study, we found statistically significant differences in the distribution of ILIRAP rs4624606 genotypes (TT, TA an AA) between males with atrophic AMD and controls: $50 \%$, $42.9 \%$ and $7.1 \%$ vs. $69.7 \%, 30.3 \%$ and $0 \%$, respectively $(p=0.015)$.

In large genome-wide case-control studies, ILIRAP was found to be associated with Alzheimer's disease (32). The same gene polymorphism was analyzed in patients with cardiovascular heart disease risk by $\mathrm{Wu}$ and colleagues (33). The study has shown that rs46246 is nominally associated with CHD risk. The AA genotype was associated with a 1.85 -fold increased risk of CHD $(p=0.045)$ compared to the TT genotype. Further analysis showed that AA carriers also had a higher risk of CHD than TT+TA carriers [odds ratio $(p=0.043)$ ] (33).

Genetic variants in $I L-1 R A c P$ have been associated with prostate cancer, Kawasaki disease, and persistent hepatitis B virus (33-36). Menon et al. have also reported that rs4624606 was associated with higher amniotic fluid-1 $\beta$ concentrations (37). IL1RAP may also play a role in acute myeloid leukemia (AML) as well as in high-risk myelodysplastic syndromes, hematologic malignancies that often progress to AML (38-41).

\section{Conclusion}

Our results showed that ILIRLI rs1041973 and ILIRAP rs4624606 gene polymorphisms may not play a role in early and exudative AMD development but IL1RAP rs4624606 may be associated with atrophic AMD in males. Also, IL1RL1 rs1041973 gene polymorphism possibly plays a protective role against macular thickening in exudative AMD patients. Further research should focus on determining the IL1RL1 and IL1RAP protein expression associations with AMD development.

\section{Data Availability}

The genotyping and ophthalmological test data used to support the findings of this study are available from the corresponding author upon request.

\section{Supplementary Material}

Available at: https://docs.google.com/document/d/1gTl2gNFba2TD 6z5nIvtAV_TPJjTEwmHAzPrr_hQsyw0/edit

\section{Conflicts of Interest}

None of the Authors has any proprietary interests or conflicts of interest related to this submission.

\section{Authors' Contributions}

Conceptualization, A.V., N.B., L.K., R.Z., and R.L.; Methodology, A.V., N.B., R.M., D.C., L.K., and R.L.; Formal Analysis, A.V., N.B., L.K., D.C., J.B., R.Z., and R.L.; Investigation, A.V., N.B., L.K., R.M., D.C., J.B., R.Z., and R.L.; Data Curation, A.V., N.B., R.M., D.C., J.B., R.Z., and R.L.; Writing - Original Draft Preparation, A.V., N.B., D.C., R.M., L.K., R.Z., J.B., and R.L.; Writing - Review \& Editing, N. B., A.V., and R.L; Supervision, R.L.

\section{References}

1 Ding X, Patel M and Chan CC: Molecular pathology of agerelated macular degeneration. Prog Retin Eye Res 28(1): 1-18, 2009. PMID: 19026761. DOI: 10.1016/j.preteyeres.2008.10.001

2 Swaroop A, Chew EY, Rickman CB and Abecasis GR: Unraveling a multifactorial late-onset disease: from genetic susceptibility to disease mechanisms for age-related macular degeneration. Annu Rev Genomics Hum Genet 10: 19-43, 2009. PMID: 19405847. DOI: 10.1146/annurev.genom.9.081307. 164350

3 Lim LS, Mitchell P, Seddon JM, Holz FG and Wong TY: Agerelated macular degeneration. Lancet 379(9827): 1728-1738, 2012. PMID: 22559899. DOI: 10.1016/S0140-6736(12)60282-7 
4 Kumaramanickavel G: Age-related macular degeneration: Genetics and biology. Asia Pac J Ophthalmol (Phila) 5(4): 229-235, 2016. PMID: 27488064. DOI: 10.1097/APO.0000000000000223

5 Wong WL, Su X, Li X, Cheung CM, Klein R, Cheng CY and Wong TY: Global prevalence of age-related macular degeneration and disease burden projection for 2020 and 2040: a systematic review and meta-analysis. Lancet Glob Health 2(2): e106-16, 2014. PMID: 25104651. DOI: 10.1016/S2214-109X(13)70145-1

6 Gorin MB: Genetic insights into age-related macular degeneration: controversies addressing risk, causality, and therapeutics. Mol Aspects Med 33(4): 467-486, 2012. PMID: 22561651. DOI: 10.1016/j.mam.2012.04.004

7 Miller JW: Age-related macular degeneration revisited-piecing the puzzle: the LXIX Edward Jackson memorial lecture. Am J Ophthalmol 155(1): 1-35.e13, 2013. PMID: 23245386. DOI: 10.1016/j.ajo.2012.10.018

8 Ferris FL 3rd, Wilkinson CP, Bird A, Chakravarthy U, Chew E, Csaky K, Sadda SR and Beckman Initiative for Macular Research Classification Committee: Clinical classification of age-related macular degeneration. Ophthalmology 120(4): 844-851, 2013. PMID: 23332590. DOI: 10.1016/j.ophtha.2012.10.036

9 Fritsche LG, Chen W, Schu M, Yaspan BL, Yu Y, Thorleifsson G, Zack DJ, Arakawa S, Cipriani V, Ripke S, Igo RP Jr, Buitendijk GH, Sim X, Weeks DE, Guymer RH, Merriam JE, Francis PJ, Hannum G, Agarwal A, Armbrecht AM, Audo I, Aung T, Barile GR, Benchaboune M, Bird AC, Bishop PN, Branham KE, Brooks M, Brucker AJ, Cade WH, Cain MS, Campochiaro PA, Chan CC, Cheng CY, Chew EY, Chin KA, Chowers I, Clayton DG, Cojocaru R, Conley YP, Cornes BK, Daly MJ, Dhillon B, Edwards AO, Evangelou E, Fagerness J, Ferreyra HA, Friedman JS, Geirsdottir A, George RJ, Gieger C, Gupta N, Hagstrom SA, Harding SP, Haritoglou C, Heckenlively JR, Holz FG, Hughes G, Ioannidis JP, Ishibashi T, Joseph P, Jun G, Kamatani Y, Katsanis N, N Keilhauer C, Khan JC, Kim IK, Kiyohara Y, Klein BE, Klein R, Kovach JL, Kozak I, Lee CJ, Lee KE, Lichtner P, Lotery AJ, Meitinger T, Mitchell P, Mohand-Saïd S, Moore AT, Morgan DJ, Morrison MA, Myers CE, Naj AC, Nakamura Y, Okada Y, Orlin A, Ortube MC, Othman MI, Pappas C, Park KH, Pauer GJ, Peachey NS, Poch O, Priya RR, Reynolds R, Richardson AJ, Ripp R, Rudolph G, Ryu E, Sahel JA, Schaumberg DA, Scholl HP, Schwartz SG, Scott WK, Shahid H, Sigurdsson H, Silvestri G, Sivakumaran TA, Smith RT, Sobrin L, Souied EH, Stambolian DE, Stefansson H, Sturgill-Short GM, Takahashi A, Tosakulwong $\mathrm{N}$, Truitt BJ, Tsironi EE, Uitterlinden AG, van Duijn CM, Vijaya L, Vingerling JR, Vithana EN, Webster AR, Wichmann HE, Winkler TW, Wong TY, Wright AF, Zelenika D, Zhang M, Zhao L, Zhang K, Klein ML, Hageman GS, Lathrop GM, Stefansson K, Allikmets R, Baird PN, Gorin MB, Wang JJ, Klaver CC, Seddon JM, Pericak-Vance MA, Iyengar SK, Yates JR, Swaroop A, Weber BH, Kubo M, Deangelis MM, Léveillard T, Thorsteinsdottir U, Haines JL, Farrer LA, Heid IM, Abecasis GR and AMD Gene Consortium: Seven new loci associated with agerelated macular degeneration. Nat Genet 45(4): 433-439, 439e12, 2013. PMID: 23455636. DOI: $10.1038 / \mathrm{ng} .2578$

10 Fritsche LG, Igl W, Bailey JN, Grassmann F, Sengupta S, BraggGresham JL, Burdon KP, Hebbring SJ, Wen C, Gorski M, Kim IK, Cho D, Zack D, Souied E, Scholl HP, Bala E, Lee KE, Hunter DJ, Sardell RJ, Mitchell P, Merriam JE, Cipriani V, Hoffman JD, Schick T, Lechanteur YT, Guymer RH, Johnson MP, Jiang Y, Stanton CM, Buitendijk GH, Zhan X, Kwong AM, Boleda A, Brooks M, Gieser
L, Ratnapriya R, Branham KE, Foerster JR, Heckenlively JR, Othman MI, Vote BJ, Liang HH, Souzeau E, McAllister IL, Isaacs T, Hall J, Lake S, Mackey DA, Constable IJ, Craig JE, Kitchner TE, Yang Z, Su Z, Luo H, Chen D, Ouyang H, Flagg K, Lin D, Mao G, Ferreyra H, Stark K, von Strachwitz CN, Wolf A, Brandl C, Rudolph G, Olden M, Morrison MA, Morgan DJ, Schu M, Ahn J, Silvestri G, Tsironi EE, Park KH, Farrer LA, Orlin A, Brucker A, Li M, Curcio CA, Mohand-Saïd S, Sahel JA, Audo I, Benchaboune M, Cree AJ, Rennie CA, Goverdhan SV, Grunin M, Hagbi-Levi S, Campochiaro P, Katsanis N, Holz FG, Blond F, Blanché H, Deleuze JF, Igo RP Jr, Truitt B, Peachey NS, Meuer SM, Myers CE, Moore EL, Klein R, Hauser MA, Postel EA, Courtenay MD, Schwartz SG, Kovach JL, Scott WK, Liew G, Tan AG, Gopinath B, Merriam JC, Smith RT, Khan JC, Shahid H, Moore AT, McGrath JA, Laux R, Brantley MA Jr, Agarwal A, Ersoy L, Caramoy A, Langmann T, Saksens NT, de Jong EK, Hoyng CB, Cain MS, Richardson AJ, Martin TM, Blangero J, Weeks DE, Dhillon B, van Duijn CM, Doheny KF, Romm J, Klaver CC, Hayward C, Gorin MB, Klein ML, Baird PN, den Hollander AI, Fauser S, Yates JR, Allikmets R, Wang JJ, Schaumberg DA, Klein BE, Hagstrom SA, Chowers I, Lotery AJ, Léveillard T, Zhang K, Brilliant MH, Hewitt AW, Swaroop A, Chew EY, Pericak-Vance MA, DeAngelis M, Stambolian D, Haines JL, Iyengar SK, Weber BH, Abecasis GR and Heid IM: A large genome-wide association study of age-related macular degeneration highlights contributions of rare and common variants. Nat Genet 48(2): 134-143, 2016. PMID: 26691988. DOI: 10.1038/ng.3448

11 Brint EK, Xu D, Liu H, Dunne A, McKenzie AN, O’Neill LA and Liew FY: ST2 is an inhibitor of interleukin 1 receptor and Toll-like receptor 4 signaling and maintains endotoxin tolerance. Nat Immunol 5(4): 373-379, 2004. PMID: 15004556. DOI: $10.1038 / \mathrm{ni} 1050$

12 Goldbach-Mansky R and Kastner DL: Autoinflammation: the prominent role of IL-1 in monogenic autoinflammatory diseases and implications for common illnesses. J Allergy Clin Immunol 124(6): 1141-1149; quiz 1150-1151, 2009. PMID: 20004775. DOI: $10.1016 /$ j.jaci.2009.11.016

13 Garlanda C, Dinarello CA and Mantovani A: The interleukin-1 family: back to the future. Immunity 39(6): 1003-1018, 2013. PMID: 24332029. DOI: 10.1016/j.immuni.2013.11.010

14 Marneros AG: Increased VEGF-A promotes multiple distinct aging diseases of the eye through shared pathomechanisms. EMBO Mol Med 8(3): 208-231, 2016. PMID: 26912740. DOI: 10.15252/emmm.201505613

15 Liutkeviciene R, Vilkeviciute A, Streleckiene G, Kriauciuniene L, Chaleckis R and Deltuva VP: Associations of cholesteryl ester transfer protein (CETP) gene variants with predisposition to agerelated macular degeneration. Gene 636: 30-35, 2017. PMID: 28918250. DOI: 10.1016/j.gene.2017.09.022

16 Age-Related Eye Disease Study Research Group: The AgeRelated Eye Disease Study system for classifying age-related macular degeneration from stereoscopic color fundus photographs: the Age-Related Eye Disease Study Report Number 6. Am J Ophthalmol 132(5): 668-681, 2001. PMID: 11704028. DOI: 10.1016/s0002-9394(01)01218-1

17 Dale $\mathrm{M}$ and Nicklin MJ: Interleukin-1 receptor cluster: gene organization of IL1R2, IL1R1, IL1RL2 (IL-1Rrp2), IL1RL1 (T1/ST2), and IL18R1 (IL-1Rrp) on human chromosome 2q. Genomics 57(1): 177-179, 1999. PMID: 10191101. DOI: 10.1006/geno.1999.5767 
18 Kumar S, Tzimas MN, Griswold DE and Young PR: Expression of ST2, an interleukin-1 receptor homologue, is induced by proinflammatory stimuli. Biochem Biophys Res Commun 235(3): 474-478, 1997. PMID: 9207179. DOI: 10.1006/bbrc. 1997.6810

19 Löhning M, Stroehmann A, Coyle AJ, Grogan JL, Lin S, Gutierrez-Ramos JC, Levinson D, Radbruch A and Kamradt T: T1/ST2 is preferentially expressed on murine Th2 cells, independent of interleukin 4, interleukin 5, and interleukin 10, and important for Th2 effector function. Proc Natl Acad Sci USA 95(12): 6930-6935, 1998. PMID: 9618516. DOI: 10.1073/ pnas.95.12.6930

20 Oshikawa K, Kuroiwa K, Tago K, Iwahana H, Yanagisawa K, Ohno S, Tominaga SI and Sugiyama Y: Elevated soluble ST2 protein levels in sera of patients with asthma with an acute exacerbation. Am J Respir Crit Care Med 164(2): 277-281, 2001. PMID: 11463601. DOI: 10.1164/ajrccm.164.2.2008120

21 Eggers KM, Armstrong PW, Califf RM, Simoons ML, Venge P, Wallentin L and James SK: ST2 and mortality in non-ST-segment elevation acute coronary syndrome. Am Heart J 159(5): 788-794, 2010. PMID: 20435187. DOI: 10.1016/j.ahj.2010.02.022

22 Näkki A, Kouhia ST, Saarela J, Harilainen A, Tallroth K, Videman T, Battié MC, Kaprio J, Peltonen L and Kujala UM: Allelic variants of IL1R1 gene associate with severe hand osteoarthritis. BMC Med Genet 11: 50, 2010. PMID: 20353565. DOI: $10.1186 / 1471-2350-11-50$

23 Hacker S, Lambers C, Pollreisz A, Hoetzenecker K, Lichtenauer M, Mangold A, Niederpold T, Hacker A, Lang G, Dworschak M, Vukovich T, Gerner C, Klepetko W and Ankersmit HJ: Increased soluble serum markers caspase-cleaved cytokeratin-18, histones, and ST2 indicate apoptotic turnover and chronic immune response in COPD. J Clin Lab Anal 23(6): 372-379, 2009. PMID: 19927353 . DOI: $10.1002 /$ jcla 20348

24 Szerafin T, Niederpold T, Mangold A, Hoetzenecker K, Hacker S, Roth G, Lichtenauer M, Dworschak M, Wolner E and Ankersmit HJ: Secretion of soluble ST2 - possible explanation for systemic immunosuppression after heart surgery. Thorac Cardiovasc Surg 57(1): 25-29, 2009. PMID: 19169993. DOI: 10.1055/s-2008-1039044

25 Martinez-Rumayor A, Camargo CA, Green SM, Baggish AL, O'Donoghue $M$ and Januzzi JL: Soluble ST2 plasma concentrations predict 1-year mortality in acutely dyspneic emergency department patients with pulmonary disease. Am J Clin Pathol 130(4): 578-584, 2008. PMID: 18794051. DOI: 10.1309/WMG2BFRC97MKKQKP

26 Reijmerink NE, Postma DS, Bruinenberg M, Nolte IM, Meyers DA, Bleecker ER and Koppelman GH. Association of IL1RL1, IL18R1, and IL18RAP gene cluster polymorphisms with asthma and atopy. J Allergy Clin Immunol 122(3): 651-4.e8, 2008. PMID: 18774397. DOI: 10.1016/j.jaci.2008.06.030

27 Zhu G, Whyte MK, Vestbo J, Carlsen K, Carlsen KH, Lenney W, Silverman M, Helms P and Pillai SG: Interleukin 18 receptor 1 gene polymorphisms are associated with asthma. Eur J Hum Genet 16(9): 1083-1090, 2008. PMID: 18382474. DOI: 10.1038/ ejhg.2008.67

28 Gudbjartsson DF, Bjornsdottir US, Halapi E, Helgadottir A, Sulem P, Jonsdottir GM, Thorleifsson G, Helgadottir H, Steinthorsdottir V, Stefansson H, Williams C, Hui J, Beilby J, Warrington NM, James A, Palmer LJ, Koppelman GH, Heinzmann A, Krueger M, Boezen HM, Wheatley A, Altmuller
J, Shin HD, Uh ST, Cheong HS, Jonsdottir B, Gislason D, Park CS, Rasmussen LM, Porsbjerg C, Hansen JW, Backer V, Werge T, Janson C, Jönsson UB, Ng MC, Chan J, So WY, Ma R, Shah SH, Granger CB, Quyyumi AA, Levey AI, Vaccarino V, Reilly MP, Rader DJ, Williams MJ, van Rij AM, Jones GT, Trabetti E, Malerba G, Pignatti PF, Boner A, Pescollderungg L, Girelli D, Olivieri O, Martinelli N, Ludviksson BR, Ludviksdottir D, Eyjolfsson GI, Arnar D, Thorgeirsson G, Deichmann K, Thompson PJ, Wjst M, Hall IP, Postma DS, Gislason T, Gulcher J, Kong A, Jonsdottir I, Thorsteinsdottir U and Stefansson K: Sequence variants affecting eosinophil numbers associate with asthma and myocardial infarction. Nat Genet 41(3): 342-327, 2009. PMID: 19198610. DOI: $10.1038 /$ ng.323

29 O'Neill LA: The interleukin-1 receptor/Toll-like receptor superfamily: signal transduction during inflammation and host defense. Sci STKE 2000(44): re1, 2000. PMID: 11752602. DOI: 10.1126/stke.2000.44.re1

30 Dale M, Hammond DW, Cox A and Nicklin MJ: The human gene encoding the interleukin-1 receptor accessory protein (IL1RAP) maps to chromosome $3 \mathrm{q} 28$ by fluorescence in situ hybridization and radiation hybrid mapping. Genomics 47(2): 325-326, 1998. PMID: 9479509. DOI: 10.1006/geno.1997.5113

31 Theodoropoulou S, Copland DA, Liu J, Wu J, Gardner PJ, Ozaki E, Doyle SL, Campbell M and Dick AD: Interleukin-33 regulates tissue remodelling and inhibits angiogenesis in the eye. J Pathol 241(1): 45-56, 2017. PMID: 27701734. DOI: 10.1002/path.4816

32 Ramanan VK, Risacher SL, Nho K, Kim S, Shen L, McDonald BC, Yoder KK, Hutchins GD, West JD, Tallman EF, Gao S, Foroud TM, Farlow MR, De Jager PL, Bennett DA, Aisen PS, Petersen RC, Jack CR Jr, Toga AW, Green RC, Jagust WJ, Weiner MW, Saykin AJ and Alzheimer's Disease Neuroimaging Initiative (ADNI): GWAS of longitudinal amyloid accumulation on 18F-florbetapir PET in Alzheimer's disease implicates microglial activation gene IL1RAP. Brain 138(Pt 10): 30763088, 2015. PMID: 26268530. DOI: 10.1093/brain/awv231

$33 \mathrm{Wu}$ F, He M, Wen Q, Zhang W, Yang J, Zhang X, Wu T and Cheng L: Associations between variants in IL-33/ST2 signaling pathway genes and coronary heart disease risk. Int J Mol Sci 15(12): 23227-23239, 2014. PMID: 25517029. DOI: 10.3390/ ijms 151223227

34 Kim JJ, Hong YM, Sohn S, Jang GY, Ha KS, Yun SW, Han MK, Lee KY, Song MS, Lee HD, Kim DS, Lee JE, Shin ES, Jang JH, Lee YS, Kim SY, Lee JY, Han BG, Wu JY, Kim KJ, Park YM, Seo EJ, Park IS, Lee JK and Korean Kawasaki Disease Genetics Consortium: A genome-wide association analysis reveals 1p31 and 2 p13.3 as susceptibility loci for Kawasaki disease. Hum Genet 129(5): 487-495, 2011. PMID: 21221998. DOI: $10.1007 /$ s00439-010-0937-x

35 Zheng SL, Liu W, Wiklund F, Dimitrov L, Bälter K, Sun J, Adami HO, Johansson JE, Sun J, Chang B, Loza M, Turner AR, Bleecker ER, Meyers DA, Carpten JD, Duggan D, Isaacs WB, $\mathrm{Xu} \mathrm{J}$ and Grönberg $\mathrm{H}$ : A comprehensive association study for genes in inflammation pathway provides support for their roles in prostate cancer risk in the CAPS study. Prostate 66(14): 15561564, 2006. PMID: 16921508. DOI: 10.1002/pros.20496

36 Kim SS, Cheong JY, Lee D, Lee SK, Kim MH, Kwack K, Yang SJ, Lee HY and Cho SW: Interleukin-1 $\beta$ and interleukin-1 receptor accessory protein gene polymorphisms are associated with persistent hepatitis B virus infection. Hepatogastroenterology 59(113): 190-197, 2012. PMID: 22251538. DOI: 10.5754/hge10375 
37 Menon R, Fortunato SJ, Edwards DR and Williams SM: Association of genetic variants, ethnicity and preterm birth with amniotic fluid cytokine concentrations. Ann Hum Genet 74(2): 165-183, 2010. PMID: 20369436. DOI: 10.1111/j.14691809.2010.00562.x

38 Barreyro L, Will B, Bartholdy B, Zhou L, Todorova TI, Stanley RF, Ben-Neriah S, Montagna C, Parekh S, Pellagatti A, Boultwood J, Paietta E, Ketterling RP, Cripe L, Fernandez HF Greenberg PL, Tallman MS, Steidl C, Mitsiades CS, Verma A and Steidl U: Overexpression of IL-1 receptor accessory protein in stem and progenitor cells and outcome correlation in AML and MDS. Blood 120(6): 1290-1298, 2012. PMID: 22723552. DOI: $10.1182 /$ blood-2012-01-404699

39 Askmyr M, Ågerstam H, Hansen N, Gordon S, Arvanitakis A, Rissler M, Juliusson $\mathrm{G}$, Richter $\mathrm{J}$, Järås $\mathrm{M}$ and Fioretos T: Selective killing of candidate AML stem cells by antibody targeting of IL1RAP. Blood 121(18): 3709-3713, 2013. PMID: 23479569. DOI: $10.1182 /$ blood-2012-09-458935
40 Ho TC, LaMere M, Stevens BM, Ashton JM, Myers JR, O'Dwyer KM, Liesveld JL, Mendler JH, Guzman M, Morrissette JD, Zhao J, Wang ES, Wetzler M, Jordan CT and Becker MW: Evolution of acute myelogenous leukemia stem cell properties after treatment and progression. Blood 128(13): 16711678, 2016. PMID: 27421961. DOI: 10.1182/blood-2016-02695312

41 Sadovnik I, Herrmann H, Eisenwort G, Blatt K, Hoermann G, Mueller N, Sperr WR and Valent P: Expression of CD25 on leukemic stem cells in BCR-ABL1+CML: Potential diagnostic value and functional implications. Exp Hematol 51: 17-24, 2017. PMID: 28457753. DOI: 10.1016/j.exphem.2017.04.003

Received June 16, 2020

Revised July 6, 2020

Accepted July 7, 2020 